\title{
Influence before and after Early Mobilization of Changes in Pain Levels in Post Orthopedic Surgery Patients at Royal Prima Medan Hospital in 2021
}

\author{
$\underline{\text { Zhan Chengwu }}^{1}$, Florenly ${ }^{2}$, Johannes Bastira Ginting ${ }^{3}$, Fioni ${ }^{4}$ \\ 1,2,3,4 Departement of Medicine, Faculty of Medicine, University of Prima Indonesia \\ Email: johannesbastiraginting@unprimdn.ac.id
}

\begin{abstract}
:
Orthopedic surgery is a surgical action associated with the correction of musculoskeletal system deformities and orthopedic problems that aim to improve function by restoring movement and stability and reducing pain and disabilities. Early mobilization is a prominent factor in speeding up postoperative recovery and may prevent postoperative complications. This study aims to find out the influence before and after early mobilization of changes in pain levels in orthopedic postoperative clients at RSU Royal Prima. This type of research uses a correlational descriptive research design, using the One Group Pretest-Postest approach. The location of this study was conducted at RSU Royal Prima Medan in March 2021. The population of all patients' post-surgery orthopedic hospitalization amounted to 176 patients. The size of the sample uses the formula Structural Equation Modelling (SEM), then the number of samples is determined to be 100 people. Univariate analysis, bivariate with $t$-dependent test (paired t-test) with a meaningful limit of 0.05 . The results of the study that there was a change in the level of pain Wilcoxon test results at the time of the pre-test the result of the mean value of 3.82, at the time of the post-test test the mean value was 2.34. So the result of $Z=-5,358$ then $p$-value as much as $0.004<0.05$ so that Ho is rejected and Ha accepts. The conclusion of the level of pain before early mobilization in the client post orthopedic surgery the majority feels even more pain and the minority experience severe pain. The level of pain after early mobilization in the majority of orthopedic postoperative clients was slightly more painful and the minority felt even more pain. There is an early mobilization effect on pain changes in orthopedic postoperative clients in patients in the hospital room of RSU Royal Prima in 2021.
\end{abstract}

Keywords:

orthopaedics; pain; early mobilization

\section{Introduction}

Orthopedic surgery is a surgical action related to the correction of musculoskeletal system deformities and orthopedic problems that aim to improve function by restoring movement and stability and reducing pain and disabilities (Iswari and Florencia 2016); (Guerra, Singh, and Taylor 2015); (Lisi et al. 2017). Orthopedic surgery due to fractures is also the highest cause of death in the United States in the age range of 1 to 37 years and the fourth cause of death for all ages (Pradana et al. 2021).

Problems that are often found in post-operative are circulation problems, urinary problems, wound problems, gastrointestinal problems, and comfort security problems (Kozier, B. 2011). Surgery can cause postoperative pain in the client, this pain is usually felt 12 to 36 hours after surgery (Hamdan Hariawan, Martini Tidore 2020); (Potter \& Perry 2010). Pain is subjective, no two individuals experience the same pain and no two events of the same pain produce identical responses or feelings in an individual (Pinandita 2012). 
Management of pain management in postoperative patients there are two, namely pharmacology or with drugs and non-pharmacology or without drugs, one of which is by early mobilization intervention. Early mobilization is a prominent factor in speeding up postoperative recovery and may prevent post-surgical complications. Research results (Caecilia and Pristahayuningtyas, Murtaqib 2016); (Fatkan, Yusuf, and Herisanti 2018) Indicate that there is an early mobilization effect on changes in the client's pain level post-appendectomy surgery. This study aims to determine the influence before and after early mobilization of changes in pain levels in orthopedic postoperative clients.

\section{Review of Literature}

Pain is one of the most important adaptive and protective mechanisms of the body and is a complex phenomenon that cannot simply be described as a response to injury. Postoperative pain is pain that is felt as a result of surgery (Rohmayani and Suwito 2017); (Suseno 2017); (Nurdin, Kiling, and Rottie 2013). Surgical pain occurs due to two things, namely due to surgical trauma that causes nociceptive stimulation and after the surgical process there is an inflammatory response in the area around the operation (Bahrudin 2018).

\section{Research Methods}

This type of research uses a correlational descriptive research design, using the One Group Pretest-Postest approach. The location of this study was conducted at RSU Royal Prima Medan in March 2021. The population of all patients' post-surgery orthopedic hospitalization amounted to 176 patients. Large sample using the formula Structural Equation Modelling (SEM), then the number of samples determined 100 people (Hair et al. 2010).

The selection of samples with non-probability sampling is consecutive sampling. Sample inclusion criteria, namely:

a) Orthopedic post-surgery patients treated at RSU Royal Prima

b) Patients who were in place when the researcher conducted the study.

c) Vital signs (blood pressure, pulse, temperature and breathing) of stable patients.

d) Patients who are willing to be responders.

Sample exclusion criteria, namely:

a) Vital signs are unstable

b) The patient has decreased consciousness.

c) Not willing to be a respondent.

\section{Data Analysis}

Univariate analysis, bivariate with $\mathrm{t}$-dependent test (paired t-test) with an meaningful limit of 0.05 .

\section{Discussion}

\subsection{Results}

\section{a. Characteristics Respondents at Royal Prima Medan Hospital in 2021}

The characteristics of respondents are a picture of the diversity of respondents based on gender, age, education and occupation. Based on this characteristic is expected to provide a better and clearer description of the condition of the 100 respondents and their relationship to the problem and the purpose of the study. 
Table 1. Overview of Research Respondents, by Age, Gender, Education and Employment Status

\begin{tabular}{cccc}
\hline Characteristic & Category & Sum & Percentage \\
\hline \multirow{2}{*}{ Age } & $<30$ Years & 10 & $10 \%$ \\
\cline { 2 - 4 } & $30 \mathrm{~s} / \mathrm{d} 40$ Years & 18 & $18 \%$ \\
\cline { 2 - 4 } & $41 \mathrm{~s} / \mathrm{d} 50$ Years & 18 & $18 \%$ \\
\hline \multirow{2}{*}{ Gender } & $>50$ Years & 54 & $54 \%$ \\
\cline { 2 - 4 } & Man & 65 & $65 \%$ \\
\cline { 2 - 4 } Education & SMP (Junior high school) & 35 & $35 \%$ \\
\cline { 2 - 4 } & SMA (High school) & 18 & $18 \%$ \\
\hline \multirow{2}{*}{$\begin{array}{c}\text { Employment } \\
\text { Status }\end{array}$} & Higher Education (D3, S1, S2, S3) & 59 & $23 \%$ \\
\cline { 2 - 4 } & PNS (state officials) & 25 & $25 \%$ \\
\cline { 2 - 4 } & Private & 29 & $29 \%$ \\
\hline
\end{tabular}

Source: Primary data, processed 2021

Age reflects the physical condition of a person. In relation to the field of health, age can reflect the specific health care needs in a person. Based on Table 1. It is known that the largest number of respondents in the age of $>50$ years is as many as 54 patients. Gender can indicate the physical condition of a person. In relation to the field of health, gender often gives meaning to a person's physical strength. The largest number of respondents in the sex was 65 patients. The level of education reflects the level of intellect of a person. The largest number of respondents at the Higher Education Level was 59 patients. Employment status reflects a person's income level. This condition often also reflects the selection of locations for health checks. The largest number of respondents on employment status was 46 patients.

\section{b. Client Pain Level Post Orthopedic Surgery before Early Mobilization at Royal Prima Medan Hospital in 2021}

Postoperative pain is a side effect that must be suffered by those who have undergone surgery, including orthopedic surgery. The pain can be caused by attachments between tissues due to surgery. The pain is almost impossible to eliminate $100 \%$ and each person will experience different levels of pain. The level of pain can be seen on a different level of the face where $0=$ No pain, $1=$ Slight pain, $2=$ Slighter pain, $3=$ More pain, $4=$ Pain once and 5 $=$ Severe pain.

Table 2. Distribution of Frequency and Percentage of Pain Rate of Clients Post Orthopedic Surgery before Early Mobilization at Royal Prima Medan Hospital in 2021

\begin{tabular}{llcc}
\hline No & Pain Level & Sum (n) & Percentage \\
\hline 1 & Severe Pain & $\mathbf{2 3}$ & $\mathbf{2 3}$ \\
\hline
\end{tabular}




\begin{tabular}{rrrc}
\hline 2 & Pain Once & 34 & 34 \\
\hline 3 & More pain & 43 & 43 \\
\hline & TOTAL & 100 & 100 \\
\hline
\end{tabular}

Based on table 2. It is known that before early mobilization the majority of respondents felt even more pain while a minority of respondents experienced severe pain.

\section{c. Early Mobilization Carried Out by Post Orthopedic Surgery Clients at Royal Prima Medan Hospital in 2021}

Immediate mobilization step by step is very useful to help the course of healing of postoperative patients.

Table 3. Distribution of Frequency and Percentage of Early Mobilization of Orthopedic Surgery Clients at Royal Prima Medan Hospital in 2021

\begin{tabular}{rlcc}
\hline No & Early Mobilization & Sum (n) & Percentage \\
\hline 1 & Can Do Well & 57 & 57 \\
\hline 2 & Can't Do Well & 43 & 43 \\
\hline & TOTAL & 100 & 100 \\
\hline
\end{tabular}

Based on table 3. It is known that the majority of respondents who can mobilize early well while the minority cannot do well.

\section{d. Client Pain Level Post Orthopedic Surgery after Early Mobilization at Royal Prima Medan Hospital in 2021}

Table 4. Distribution of Frequency and Percentage of Pain Levels of Post Orthopedic Surgery after Early Mobilization at Royal Prima Medan Hospital in 2021

\begin{tabular}{clcc}
\hline No & Pain Level & Sum (n) & Percentage \\
\hline 1 & More pain & 34 & 34 \\
\hline 2 & A Little More Pain & 66 & 66 \\
\hline & TOTAL & 100 & 100 \\
\hline
\end{tabular}

Based on table 4. It is known that after early mobilization, the majority of respondents felt a little more pain and a minority of respondents felt even more pain.

\section{e. Pain Level Before and After Early Mobilization of Orthopedic Post Surgery Clients at Royal Prima Medan Hospital in 2021}

Table 5. Pain Levels Before and After Early Mobilization in Post Orthopedic Surgery Clients at Royal Prima Hospital

\begin{tabular}{llcccc}
\hline No & Pain Level & Sum (n) & Mean & SD & Min Max \\
\hline 1 & Early Pre-Mobilization & $\mathbf{1 0 0}$ & $\mathbf{3 . 8 2}$ & $\mathbf{0 . 8 0 1}$ & $3-5$ \\
\hline 2 & Early Post-Mobilization & $\mathbf{1 0 0}$ & $\mathbf{2 . 3 4}$ & $\mathbf{0 . 4 8 1}$ & $\mathbf{2 - 3}$ \\
\hline
\end{tabular}

Based on table 5. The average level of pain before early mobilization was 3.82 and after early mobilization, there was an average of 2.34 . The minimum value of pain level in early pre mobilization is 3 and the maximum value is 5 while in early post mobilization the minimum pain level is 2 and the maximum value is 3 . 


\section{f. Bivariate Analysis}

Based on the results of research on the effects after and before early mobilization of pain changes in orthopedic postoperative clients at RSU Royal Prima Medan in 2021.

Table 6. Results of Wilcoxon Signed Ranks Test Description of Changes in Pain Levels before and after Early Mobilization in Post Orthopedic Surgery Clients at Royal Prima Medan Hospital in 2021

\begin{tabular}{llcrrc}
\hline No & Pain Level & Sum (n) & Mean & Z & \multicolumn{1}{c}{$p$-value } \\
\hline 1 & Early Pre-Mobilization & $\mathbf{1 0 0}$ & 3.82 & -5.368 & 0,004 \\
\hline 2 & Early Post-Mobilization & 100 & 2.34 & & \\
\hline
\end{tabular}

Based on table 6. It is known that the change in pain level of wilcoxon test results at the time of the pre-test test the mean value is 3.82 , at the time of the post-test test the mean value is 2.34 . So the result of the value $Z=-5,358$ then $p$ value as much as $0.004<0.05$ so that it is concluded ho rejected and Ha received, which means there is an influence of early mobilization of pain changes in orthopedic post surgery clients in the room of RSU Royal Prima in 2021.

\subsection{Discussion}

a. Pain Level before Early Mobilization to Clients Post Orthopedic Surgery at Royal Prima Medan Hospital in 2021

Research results (Huang et al. 2001) 25-50\% of orthopedic patients report pain on a severe scale after undergoing surgery. Research in Turkey, Aslan (2006) It also explains that acute pain occurs in 39-97\% of post orthopedic surgery patients (Büyükyilmaz, Şendir, and Acaroğlu 2011); (Iswari and Florencia 2016). Pain is a highly individualized and subjective experience that can affect everyone at any age. Pain can occur in children and adults. Causes of pain are the process of disease, injury, procedures, and surgical interventions (S Kyle, T \& Carman 2015); (Wahezi et al. 2020). Based on the results of a study of 100 respondents on the effect of early mobilization of pain changes in orthopedic postoperative clients in the hospital room of RSU Royal Prima in 2021 it is known that before early mobilization the majority of respondents felt even more pain while a minority of respondents experienced severe pain. The theory states that orthopedic postoperative pain has been reported as acute pain at severe levels. This is due to the degree of damage that hurts ranging from superficial, soft tissue, boned exposed, blood vessels and nerves (Iswari and Florencia 2016).

\section{b. Pain Level after Early Mobilization in Post Orthopedic Surgery Clients at Royal Prima Medan Hospital in 2021}

Pain can be defined as something elusive and a complex phenomenon although universal, but it is still a mystery that pain is one of the defense mechanisms of the human body that shows the experience of problems and pain is the belief of the individual and how the individual responds to pain experienced(Lynn, Lynn, and Csfn. 2011). Pain is a highly individualized and subjective experience that can affect everyone at any age. Pain can occur in children and adults. Causes of pain are the process of disease, injury, procedures, and surgical interventions (S. Kyle, T \& Carman 2015).

Pain in patients after orthopedic surgery is acute pain, caused by tissue damage that occurs not only due to surgical incisions but also previous trauma that is indicative of orthopedic fracture surgery. Nurses have a role to overcome pain, pain response and side effects of the administration of relieved pain therapy. Pain management is the collaboration of all provider services for the benefit of patients (Sasongko 2019). Based on the results of a 
study of 100 respondents on the effect of early mobilization of pain changes in orthopedic postoperative clients in the hospital room of RSU Royal Prima in 2021 it is known that after being given early mobilization the majority of respondents felt slightly more pain and a minority of respondents felt even more pain.

\section{c. Influence of Early Mobilization of Pain Levels in Orthopedic Post Surgery Clients at Royal Prima Medan Hospital in 2021}

The results of the study from the Wilxocon Rank Test showed $\varrho$-value $=0.004<\alpha=$ 0.05 , this means $\mathrm{H} 0$ was rejected and $\mathrm{Ha}$ received an early mobilization effect on pain changes in orthopedic post-surgery clients in patients in the Hospital room of RSU Royal Prima in 2021. The results of this study are by the opinion Pristahayuningtyas, et.al (2016) which shows that there is an early mobilization effect on changes in the client's pain level post orthopedic surgery. This research is also by Fatkan, et.al (2018), which shows that early mobilization can reduce the pain level of the client post appendectomy surgery (Fatkan et al. 2018).

\section{Conclusion}

This study concludes that the level of pain before early mobilization in orthopedic postoperative clients the majority feels even more pain and the minority experience severe pain. The level of pain after early mobilization in the majority of orthopedic postoperative clients was slightly more painful and the minority felt even more pain. There is an early mobilization effect on pain changes in orthopedic postoperative clients in patients in the RSU Royal Prima hospital room in 2021.

\section{References}

Bahrudin, Mochamad. 2018. "Patofisiologi Nyeri (Pain)." Saintika Medika 13(1):7.

Büyükyilmaz, Funda Esen, Merdiye Şendir, and Rengin Acaroğlu. 2011. "Evaluation of NightTime Pain Characteristics and Quality of Sleep in Postoperative Turkish Orthopedic Patients." Clinical Nursing Research 20(3):326-42.

Caecilia, Rr Yudistika, and Siswoyo Pristahayuningtyas, Murtaqib. 2016. "Pengaruh Mobilisasi Dini Terhadap Perubahan Tingkat Nyeri Klien Post Operasi Apendektomi Di Rumah Sakit Baladhika Husada Kabupaten Jember.” E-Jurnal Pustaka Kesehatan 4(1):1-6.

Fatkan, Moch, Ah. Yusuf, and Wesiana Herisanti. 2018. "Pengaruh Kombinasi Mobilisasi Dini Dan Relaksasi Spiritual Terhadap Tingkat Nyeri Klien Post Operasi Apendektomi." Jurnal Universitas Nahdlatul Ulama Surabaya 1(1):117-24.

Guerra, Mark L., Parminder J. Singh, and Nicholas F. Taylor. 2015. "Early Mobilization of Patients Who Have Had a Hip or Knee Joint Replacement Reduces Length of Stay in Hospital: A Systematic Review." Clinical Rehabilitation 29(9):844-54.

Hair, Joseph, William Black, Barry Babin, and Rolph Anderson. 2010. Multivariate Data Analysis: A Global Perspective.

Hamdan Hariawan, Martini Tidore, Greeny Z. Rahakbau. 2020. "Vol. 2 No. 1 April 2020." Perilaku Pencegahan Penyakit Tidak Menular Pada Remaja Ambon 2(1):16.

Huang, Nina, Francesca Cunningham, Charles E. Laurito, and Connie Chen. 2001. "Can We Do Better with Postoperative Pain Management?" American Journal of Surgery 182(5):440-48.

Iswari, and Miranti Florencia. 2016. "Gambaran Tingkat Nyeri Dan Kecemasan Pasien Post Operasi Orthopedi Di Rumah Sakit Muhammadiyah Palembang." Masker Medika 4(2):211-19. 
Kozier, B. 2011. Buku Ajar Fundamental Keperawatan. Jakarta: EGC.

Kyle, T \& Carman, S. 2015. Buku Praktik Keperawatan Pediatri. Jakarta: EGC.

Kyle, T \& Carman, S. 2015. Buku Praktik Keperawatan Pediatri. Jakarta: EGC.

Lisi, Claudio, Patrick Caspani, Marco Bruggi, Ettore Carlisi, Donatella Scolè, Francesco Benazzo, and Elena Dalla Toffola. 2017. "Early Rehabilitation after Elective Total Knee Arthroplasty." Acta Biomedica 88(3):56-61.

Lynn, Pamela Ann, Pamela Barbara Lynn, and Carol Taylor Csfn. 2011. Taylor's Clinical Nursing Skills: A Nursing Process Approach.

Nurdin, S., M. Kiling, and J. Rottie. 2013. "Pengaruh Teknik Relaksasi terhadap Intensitas Nyeri pada Pasien Post Operasi Fraktur di Ruang Irina A Blu Rsup Prof Dr. R.D Kandou Manado.” Jurnal Keperawatan UNSRAT 1(1):106506.

Pinandita, I. et. a. 2012. "Jurnal Ilmiah Kesehatan Keperawatan, Volume 8, No. 1, Februari 2012." Jurnah Kesehatan Perawatan 8(1):32-43.

Potter \& Perry. 2010. Fundamental of Nursing: Consep, Proses and Practice. 7th ed. Jakarta: EGC.

Pradana, Putra, Program Studi, Ilmu Keperawatan, Fakultas Ilmu Kesehatan, and Universitas Muhammadiyah Surakarta. 2021. "Fraktur yang Menyandang Hipertensi di RS." Program Studi Ilmu Keperawatan Fakultas Ilmu Kesehatan Universitas Muhammadiyah Surakarta.

Rohmayani, Maya Safitri, and Joko Suwito. 2017. "Intensitas Nyeri Klien Pasca Operasi Mayor Di Rumah Sakit Islam Jemursari Surabaya." Jutnal Keperawatan XII (1):23-29.

Sasongko, et al. 2019. "The Effects of Combination of Range Motion and Deep Breathing Exercise on Pain in Post-Orthopedic Surgery Patients." Indonesian Journal of Medicine 4(1):46-53.

Suseno, Endy. 2017. "Pencegahan Nyeri Kronis Pasca Operasi." Majalah Kedokteran Andalas 40(1):40.

Wahezi, Sayed, Robert A. Duarte, Sandeep Yerra, Mark A. Thomas, Beendu Pujar, Nalini Sehgal, Charles Argoff, Laxmaiah Manchikanti, David Gonzalez, Ruchi Jain, Chong Kim, Michael Hossack, Shayan Senthelal, Ankush Jain, Nathanael Leo, Naum Shaparin, Daniel Wong, Ashley Wong, Kim Nguyen, Jaspal Ricky Singh, Giacinto Grieco, Arpan Patel, Merritt D. Kinon, and Alan David Kaye. 2020. "Telemedicine during Covid-19 and beyond: A Practical Guide and Best Practices Multidisciplinary Approach for the Orthopedic and Neurologic Pain Physical Examination." Pain Physician 23(4 Special Issue):S205-37. 